\title{
COOPERATIVES, OPPORTUNISM AND QUALITY PRODUCT: WHY THE EARLY SPANISH COOPERATIVE WINERIES PRODUCED ORDINARY WINE
}

\author{
Samuel Garrido \\ (Department of Economics, Universitat Jaume I)
}

\begin{abstract}
Cooperative wineries have always produced mostly low-quality wine. Since they began to receive abundant state subsidies in the period following the Second World War, they have produced a substantial part of all European wine, but prior to that their market share was low. This paper discusses whether both the specialisation of the first Spanish cooperative wineries in the production of ordinary wine and its poor market penetration were a result of their inability to prevent members from carrying out opportunistic behaviours. It contends that cooperative wineries were in fact capable of fighting opportunism and that producing ordinary wine was the best option for the vast majority of them, even though they did not manage to offer winegrowers advantages that were significant enough to offset the inconveniences of being members.
\end{abstract}

Keywords: cooperative wineries, wine, cooperatives, winemaking cooperatives, collective action, free-rider behaviour, opportunism, quality product, viticulture, Spain.

\section{Introduction}

Cooperative wineries emerged at the end of the nineteenth century and throughout the first half of the twentieth century their market share was low in all countries. From around 1950, however, the intervention of the state made it easier for them to begin to gain followers among both small and large European winegrowers. Paradoxically, this has been compatible with the fact that cooperative wineries have always had a poor reputation among wine consumers, who associate them with ordinary wine. Indeed, they have always produced mainly cheap, low quality wine. This paper uses information from Spain, accompanied by numerous references to France, with a twofold aim: to analyse why the early cooperative wineries specialised in the production of table wine (an expression that will henceforth be used as a synonym for low quality wine) and to investigate why wine cooperatives took so long to become strong.

The expansion that began in the 1950s meant that in the early twenty-first 
century cooperative wineries in the European Union had 550,000 members. ${ }^{1}$ By then, cooperatives in the world's three largest wine producers, France, Italy and Spain, were producing 52, 55 and 70 per cent of the wine in their countries. ${ }^{2}$ In contrast, in the mid1930s there were just over 100 cooperative wineries in Spain and Italy, with a market share of less than 5 per cent. In France, where the government support they had been receiving since 1906 intensified in the 1930s, there were more (503 in 1932 and 838 in 1939), but French cooperatives' achievements in terms of market share were not particularly brilliant either: less than 10 per cent in 1932 and less than 20 per cent in $1939 .^{3}$

Thanks to Eva Fernández and James Simpson, we have a solid explanation of why wine cooperation became widespread in Europe after the Second World War. As in France in the 1930s, but now in a more generalised fashion, governments wanted to use cooperatives to regulate markets and, to enable them to store large volumes of wine and distil it in times of over-production, they were offered low-interest loans, subsidies and bonuses, thereby enhancing their ability to attract new members. ${ }^{4}$ Yet what happened before that is not clear.

Part of the academic literature on cooperative wineries has tended to consider that they have played a very positive role since the early twentieth century. ${ }^{5}$ Another part, however, often written by wine economists, has considered that cooperative wineries have major difficulties in combating free-rider behaviour, which leads them to operate badly. ${ }^{6}$ Fernández and Simpson share the second view and claim that cooperatives were unable to control the quality of the raw material they received without incurring prohibitive costs, because they specialised in producing cheap wine and European grape was very heterogeneous in quality. ${ }^{7}$ As there was no control, those who joined a cooperative assumed that the other members would only contribute their

\footnotetext{
${ }^{1}$ Cogeca, Agricultural cooperatives.

${ }^{2}$ Fernández and Simpson, 'Product quality', p. 125.

${ }^{3}$ Own calculations based on Rouanet (Problème, p. 141) and Loubère (Wine, p. 139).

${ }^{4}$ Fernández and Simpson, 'Product quality'. See also Planas and Medina-Albadalejo 'Too little'; Planas and Medina-Albadalejo, 'Bodegas'; Medina-Albadalejo, 'Co-operative wineries'.

${ }^{5}$ For example, Gavignaud-Fontaine, 'Les caves'; Rinaudo, 'Coopérative'; Piqueras, 'La vid'.

${ }^{6}$ Loubère The red; Loubère, Wine; Roudié, Vignes; Delmastro 'An investigation'; Roma et al., 'Wine labels'; Pennerstorfer and Weiss, 'Product quality'; Schamel, 'German wine'.

${ }^{7}$ Fernández and Simpson, 'Product quality'.
} 
worst grape and tended to do the same. Consequently, the wine was extremely poor quality and mutual distrust reigned among the members. This would be the reason why few cooperative wineries were created.

The argument is appealing but leaves various questions unanswered. ${ }^{8} \mathrm{In}$ southern France and Catalonia many cooperative wineries did appear. ${ }^{9}$ Substantial investment was required to build their facilities, which forced the members to go into debt. Why were people willing to get into debt to become members of a club of freeriders?

We now know that with a good system of rules and sanctions the Tragedy of the Commons can be prevented even in the commons. ${ }^{10}$ For centuries, with good rules, rudimentary techniques and much ingenuity, commoners in many places have effectively persecuted free-rider behaviour even among users of flowing water, a resource that was very complicated to measure until relatively recently. ${ }^{11}$ Why were cooperatives unable to do the same with grape quality, which is apparently easier to measure?

Cooperatives are often created in response to information asymmetry problems,${ }^{12}$ but they are created by the people adversely affected by the problem, whereas, if Fernández and Simpson are correct, in wine-growing the opposite occurred. In both table wine producing areas and fine wine producing regions (Champagne, Burgundy or Jerez), small farmers would often sell their grape so that others (merchants or better-off growers) could make wine with it. ${ }^{13}$ As those who had grown the grape had better information on any defects than those who purchased it, why were cooperatives often set up by farmers who wanted to stop selling grape on the market to then sell it to

\footnotetext{
${ }^{8}$ Although in the rest of the paper I will dissent from Fernández and Simpson's thesis, 'Product quality', regarding the period before the Second World War, I became interested in cooperative wineries thanks to their stimulating article. Their ideas convinced me and I wanted to gather information to test them. But I ended up coming to the conclusion that in the early twentieth century things had not gone exactly the way they claim.

${ }^{9}$ On southern France, see Congrès, XIV Congrès. The Catalan case is analysed in a companion article to this one: Garrido, 'Inequality'. See also Planas, 'Emergence'.

${ }^{10}$ Ostrom, Governing the commons.

${ }^{11}$ Garrido, 'Water'.

12 Hansmann, 'Cooperative firms'.

${ }^{13}$ Mandeville, Étude, pp. 45-58; Planas, 'Emergence', p. 270; Bernácer, Comercio, p. 25; Piqueras, Campo Arcís; Guide, Associations, p. 141; Blic, Crise, p. 6; Torrejón, Bodegas, p. 14
} 
the company that they co-owned $?^{14}$ Meanwhile, merchants did not stop purchasing grape nor did they generally embark on backward integration processes, ${ }^{15}$ which suggests that measuring grape quality was not prohibitively expensive for them. So why was it for cooperatives?

The rest of the article is organised as follows. Section 2 argues that, given the characteristics of the demand for wine, producing quality wine would have been a bad choice for most of the first cooperatives. Sections 3 and 4 reject the idea that members were trapped in a Prisoner's Dilemma situation. Section 5 shows that, despite this, cooperative wineries were generally unable to offer their members substantial advantages over non-members. The final section contains the conclusions.

\section{Consumer preferences matter}

As the Danish cooperative dairies enjoyed spectacular success at an early stage of their development, it is practical to use them to perform a comparison with what happened in winegrowing. Good institutional design meant that in Denmark cooperatives became the most efficient way of organising butter production using automatic cream separators, which produced better butter than pre-existing technologies. In 1903 the owners of 81 per cent of Danish cows were already members of a cooperative dairy. ${ }^{16}$ Presumably, the fact that in Great Britain, the main destination for Danish butter, consumers were willing to pay more for better quality was a major requirement for this to happen, because otherwise Danish butter would not have had more demand in the British market than the cheaper and poorer quality Irish butter and the Danes would have been less motivated to use the new technology and join cooperatives.

However, Postel-Vinay and Robin showed that in mid-nineteenth century France the demand for wine had both high income elasticity and high price elasticity, so that expenditure on wine 'increased rapidly' when income improved, but 'quickly retreated'

\footnotetext{
${ }^{14}$ Sometimes cooperatives are only able to attract as members those who want to use them to offload the worst of their production (Garrido, 'Plenty of trust'). But such adverse selection processes only occur when the barriers to entry are low. Cooperative wineries, whose members had to get into debt, had high barriers to entry.

15 Simpson, Creating wine, p. 54.

${ }^{16}$ Henriksen et al., 'Role of technology'.
} 
when wine became more expensive. ${ }^{17}$ At the beginning of the twentieth century the increase in the level of income led to a rise in per capita consumption, ${ }^{18}$ but from the large amount of information gathered by Fernández and Simpson it can be seen that, throughout the whole of the Mediterranean area, the typical consumer of wine remained unwilling to pay more for better quality. ${ }^{19}$ In the late nineteenth century various scientific developments enabled winegrowers to know which controllable factors made the wine they produced drinkable, but the new 'scientific viniculture' did not serve to make the production of premium wine cheaper because of the need to use slow wine maturing processes. As a result, although in the early twentieth century frequent overproduction led to falls in the prices of table wine,${ }^{20}$ the situation did not encourage the production of better quality wine because, as 'consumers did not focus on the class of wine, but only on the cheap price of the product', ${ }^{21}$ whoever produced quality wine would most probably have to sell it at the price of table wine in order to find a market for it. ${ }^{22}$

Consequently, the immense majority of wine - on average, 97.9 per cent of that produced in France between 1907 and 1913 and 94.5 per cent of that produced in Spain between the years 1932 and 1935 - was table wine. ${ }^{23}$ Market preferences only began to change in the 1970s, first in France and then in the other countries, but by 1990 consumption of wine of a higher quality than table wine continued to represent a scanty 16 per cent of all the wine consumed in Spain and 38 per cent in France. ${ }^{24}$

For this reason, and with few exceptions, the early cooperatives produced table wine. In fact, a Spanish study intended to promote their creation advised that they

\footnotetext{
${ }^{17}$ Postel-Vinay and Robin, 'Eating', p. 504.

18 Pinilla and Ayuda, 'Market dynamism'.

${ }^{19}$ Simpson, Creating wine, especially pp. 48 and 55; Fernández, 'Especialización'.

${ }^{20}$ Pech, Entreprise; Pujol, 'Crisis'; Pan-Montojo, Bodega; Simpson, Creating wine; Planas, 'State intervention'; Fernández and Pinilla, 'Spain'.

${ }^{21}$ Flamarique, 'Cooperativas', p. 11.

${ }^{22}$ For a detailed account of the difficulties faced by a large landowner in La Rioja (Spain) who decided to specialise in the production of premium wine, see González Inchaurraga, El marqués. Raventós, Verema, pp. 78-80, reports on a similar case that occurred in Catalonia.

${ }^{23}$ Ministère du Travail et de la Prévoyance Sociales, Annuaire Statistique de la France (1907-1915);

Ministerio de Agricultura. Anuario estadístico de las producciones agrícolas (1932-1935).

${ }^{24}$ Fernández, ‘Especialización’, p. 48.
} 
should only produce 'good table wine that can be sold cheaply'. ${ }^{25}$

3. The cooperatives were able to fight free-rider behaviour

Anyone who intended to specialise in the production of quality wine had to be able to familiarise (the few) potential purchasers with the characteristics of their product. As that task was easier when wine came from areas famed for the quality of their wines, in France most cooperatives producing good wine were created (by former grape sellers) in Champagne and Burgundy. ${ }^{26} \mathrm{~A}$ few cooperatives that opted for quality also appeared in some towns in the south of the country whose wine already enjoyed certain prestige. ${ }^{27}$ In Spain, the same happened in Alella (Barcelona) and Peñafiel (Valladolid). They used to be exclusively made up of small farmers and many produced good wine with poor financial results, because they had difficulties in accessing the short-term credit required to finance the process of maturing the wine. ${ }^{28}$

It is commonly supposed that the more numerous cooperatives producing table wine were doomed to be simply passive receivers of the larger or smaller amounts of grape of any quality that the members wanted to contribute. But it is not evident that this was the case for four reasons. Firstly, the typical member was a small or mediumsize winegrower. A large part of their total income came from their transactions with the cooperative, to which they knew they would be linked for long periods. They usually knew most of the other members personally and lived near them and the cooperative. In such circumstances, investing time in order to influence affairs at the cooperative becomes profitable for members. ${ }^{29}$

Secondly, detecting whether grape quality was appropriate for producing a good table wine was not excessively expensive. Grape quality depends on sugar content (used to predict the alcohol content of the future wine), acidity, variety, maturity, colour and sanitary condition. ${ }^{30}$ Exact measurement of sugar and acidity must be performed with

\footnotetext{
25 Torrejón, Bodegas, p. 21.

${ }^{26}$ Clique, Caves.

${ }^{27}$ Mandeville, Étude, pp. 113-34.

${ }^{28}$ Mandeville, Étude, pp. 124-30; Clique, Caves coopératives, pp. 154-63; Alella Vinícola, Cincuentenario.

${ }^{29}$ Hansmann, 'Cooperative firms'.

${ }^{30}$ Robinson, Oxford companion, p. 335.
} 
laboratory instruments, but the other parameters can be appreciated through the senses and offer an approximate idea of the sugar content and acidity, which are closely linked to grape variety and maturity. ${ }^{31}$

Thirdly, there were many cheap measures that cooperatives could take to discourage opportunism. For example, they could visit the vines before the harvest to estimate the volume and quality of production. They could also not pay anything for very poor quality grape and use any revenue it provided to add a bonus to the price of the rest of the grape; in that way, most members would obtain a total income similar to that they would have obtained if all the grape had been paid for and nobody specialised in producing poor quality grape. Or, to prevent members from replacing low-yield highquality vine varieties with others of the opposite characteristics, they could pay a different price for each grape variety (or not accept certain grape varieties).

Finally, all members were individually 'imprisoned' by the investment required to build a winery, thereby enabling the collective to escape the Prisoner's Dilemma. Ingrid Henriksen and collaborators consider there were two basic factors for the success of cooperative dairies in Denmark and their relative failure in Ireland: in contrast to Ireland, the articles of association of Danish cooperatives clearly specified members' obligations (including that of not abandoning the cooperative until the end of a given term, which was usually equal to the period for repaying the loan taken out to build the facility) and the Danish legal system ensured that those obligations were binding. ${ }^{32}$ Members of cooperative wineries were also bound by rules and loans.

Most French cooperative wineries (322 of the 353 existing in late 1927) were built with government loans, which were only granted on condition that all members were joint and severally liable for repaying them. ${ }^{33}$ In direct relation to this, the cooperatives' articles of association usually obliged members to contribute all or part of their grape for 25 years or more. In the event of dispute, judges forced people leaving cooperatives to make considerable outlays ${ }^{34}$. In Spain, since 1906 the Ley de Sindicatos Agrícolas (1906 Agrarian Syndicates Act), the principal legislation on cooperation in Spanish law, stated that, regardless of what the articles of association specified,

\footnotetext{
${ }^{31}$ Badell, 'Valoración'.

${ }^{32}$ Henriksen et al., 'Law and peace'; Henriksen et al., 'Contracts'.

33 Tardy, 'Coopération', pp. 420 and 444.

${ }^{34}$ Gervais, Coopération, pp. 59-61; Mandeville, Étude, pp. 153-5; Chalmain, 'Coopérateurs'.
} 
members were free to leave whenever they wished, but were liable for all the obligations and liabilities they had contracted up until then. As a result, the articles of association of Spanish cooperatives limited themselves to indicating that members had to contribute their grape throughout the life of the loan. Consequently, when two cooperatives left a district federation which had built a distillery, with disastrous economic results, the judge made them pay a substantial amount to the federation. ${ }^{35}$ Another cooperative brought a successful claim against 19 members who wanted to change to a rival cooperative. ${ }^{36}$

Everyone was anxious to ensure that nobody totally or partially breached their obligation to contribute grape because, as in France and Italy, ${ }^{37}$ the harvest each member had undertaken to contribute determined what percentage of the shared loan he would have to repay. Repayments were made by the cooperative withholding a portion of the revenue generated by individual contributions of grape. The more grape the cooperative processed, the quicker the loan would be paid back; anyone who cheated on amounts would directly harm each of the other members.

As the next sections will explain, all of the above facilitated governance of cooperative wineries - although most winegrowers preferred not to be subject to this type of discipline and did not join them.

\section{Less opportunism than people think}

Danish cooperative dairies required members to give up their entire milk production, but cooperative wineries often did not require members to contribute all their grape. In principle, if they had done so, it would have been easier to prevent members from cheating on quantity or quality. Some cooperatives in Champagne and Burgundy, however, only wanted to receive grape suitable for producing fine wine. So, members of Burgundy cooperatives had to hand over their entire harvest of pinot fin and none of the rest. Two types of fraud were therefore possible: they could keep part of the pinot fin or they could mix it with other varieties. But according to Hubert Clique fraudulent behaviour was exceptional 'because members monitored each other, so it was difficult

\footnotetext{
${ }^{35}$ Planas and Vallès, 'Espluga'.

${ }^{36}$ Santesmases, Cooperativisme, pp. 100-3.

${ }^{37}$ Clique, Caves.
} 
for one member to cheat without another member finding out'. ${ }^{38}$ This mutual surveillance was not exclusive to cooperatives producing fine wine. ${ }^{39}$

There were two main reasons why many table-wine making cooperatives did not require all the grape. In southern France it was partly due to the fact that the vines destroyed by the phylloxera plague in the late nineteenth century were replanted with very high yielding varieties and so many farmers no longer had the capacity to store all their harvest. The cooperatives were intended to extend rather than replace private wineries so that members did not have to sell grape or must instead of wine. ${ }^{40}$ In other places (and partly in southern France as well) cooperatives adopted this policy to attempt to attract well-off winegrowers, who usually flatly refused to become members if they had to contribute all their grape. Cooperatives were interested in attracting such winegrowers because their presence made it easier to access economies of scale. ${ }^{41}$ And, above all, they made it easier to obtain loans. In France, this was because government loans to cooperatives (at 2 or 3 per cent) were intended to supplement the capital that members of cooperatives achieved through other means - they could be between one and a half and two times the amount of that capital. ${ }^{42}$ In Spain, it was due to the fact that banks only loaned to cooperatives (at 5 or 6 per cent) if the membership included very solvent individuals. ${ }^{43}$

Spanish table-wine making cooperatives that did not require their members' entire harvests used four procedures to regulate the issue. ${ }^{44}$ In some (only a few) cooperatives, members had to contribute a given fraction of their total harvest. In others (also only a few) members had to contribute all the harvest from a given number of clearly identified vines. As a third option, members undertook to deliver a fixed volume of grape. That option, as in southern France and Italy, ${ }^{45}$ was the most widely used system, because it was a way of ensuring that the cooperative facilities worked almost

\footnotetext{
${ }^{38}$ Clique, Caves, p. 59.

${ }^{39}$ Marsais, Caves, gives examples.

${ }^{40}$ Gervais, Coopération; Mandeville, Étude.

${ }^{41}$ See Congrés, XIV Congrès, p. 352, on Algeria.

42 Tardy, 'Coopération', p. 428.

${ }^{43}$ Garrido, Treballar.

44 The statements that follow are based on a reading of numerous cooperative regulations and the literature cited in footnote 45 .

${ }^{45}$ Clique, Caves.
} 
every year at full capacity and made it difficult for members to cheat on the amount of grape delivered. The fourth procedure was used by some Catalonian cooperatives, which allowed members to keep grape on farms located at more than a certain distance from its facilities (or on farms that had a winery). ${ }^{46}$

Although it has generally been assumed that such regulations did not serve to effectively combat opportunist behaviours, in Spain numerous local studies have used the documentation generated by cooperative wineries and none have provided evidence that opportunism was widespread or raised very serious problems. ${ }^{47}$ Naturally, every so often someone was found to have breached the rules, but cooperatives managed to prevent, often through very substantial fines and expulsions, ${ }^{48}$ such actions from triggering a cascade of breaches, which is what usually happens when collective action institutions are unable to punish offenders adequately. ${ }^{49}$ Those who were expelled usually lost all their rights and had to make annual payments to the cooperative until the loan had been paid off.

\section{$<<$ Figure $1>>$}

Figure 1 illustrates that such rigour was effective. We know how much grape the two Catalonian cooperatives shown in the figure received over time from a group of members known to own vines worked by sharecroppers, from a group of members known to be sharecroppers, and from the other members (including, although we do not know in what proportion, landlords, sharecroppers and small and medium-size owners). The temptation to take little grape to the cooperative in years when the market paid a lot

\footnotetext{
${ }^{46}$ Catalonian vines that were far away from cooperatives were usually on mountainous slopes and cultivated by sharecroppers. Many landlords had a winery on that type of farm, whereas sharecroppers had their wineries in the village (or had no wineries). See Garrido, 'Sharecropping'.

${ }^{47}$ Puig, Celler; Martos, 'Sindicato'; Fuguet, 'Celler'; Gavaldà, Associacionisme; Gavaldà and Santesmases, Història; Fuguet and Mayayo, Primer celler; Soto, Bodega; Santesmases, Cooperativisme; Teixidó, Societat; Saumell, Crisi; Saumell, Viticultura; Saumell, Cooperativa; Ibarra, 'Sindicat'; Muntadas, Alella Vinícola; Cárdaba and Musquera, Celler; Llorca , 'Cooperació', Mayayo, Empemta; Ferrer Alós, 'Sindicat'; Pena, Breu història; Piqueras, Campo Arcís; Planas, Viticultura; Planas, 'Características'; Audí, 100 anys; Vallès, Celler; Muruzabal, Centenario; Planas and Vallès, 'Espluga'; García, Bullas.

${ }^{48}$ Saumell, Cooperativa; Planas, Viticultura; Audí, 100 anys.

${ }^{49}$ Ostrom, Governing the commons.
} 
for it, and vice-versa, was there for everyone. But engaging in such behaviour without being discovered was easier for landlords than for sharecroppers, who almost always cultivated small plots that gave small harvests, and so cheating on modest amounts represented high percentages of the harvest. Therefore, if cheating on amounts had been as frequent as the literature supposes, the cheats would have been mainly the landlords and the evolution of the three series would have been different. According to the nonparametric tests, however, there are no significant differences among the three series, and so the variations in grape delivery must have been basically caused by inter-annual variations in the volume harvested due to factors beyond the farmer's control. ${ }^{50}$

Furthermore, it is not clear that giving the worst grape to the cooperative was always beneficial because most cooperatives paid by kilograms of grape received taking the sugar content into account, which served to penalise those who delivered grape which produced little alcohol. This was the most interesting parameter to monitor because when negotiating the price of table wine merchants focussed on the alcohol content. ${ }^{51}$ Small farmers' vines were usually on hillsides, producing low yields and wine with a very high alcohol content, whereas vines on the plains, which gave high yields and low alcohol content, usually belonged to well-off people. If the cooperatives had simply paid for grape by weight, small farmers would not have wanted to join. ${ }^{52}$

Control over the other attributes of the grape was much looser, because the

\footnotetext{
${ }^{50}$ The available data on the Marsillargues cooperative (southern France) suggest the same. We know how many hectolitres of wine were produced between 1913 and 1925 (Congrès, XIV Congrès, p. 168). After transforming the series to index numbers $(1913-1925=100)$ and performing the same operation with the hectolitres produced in southern France in the same period (Pech, Entreprise, pp. 497-8), a MannWhitney test indicates that the null hypothesis that the distributions of both series are identical cannot be rejected $(\mathrm{p}=0.42)$.

${ }^{51}$ Mandeville, Étude, p. 29; Riba, Cellers, p. 14; Cañizo, Bodegas, p. 8; Badell, 'Valoración’, p. 228.

${ }^{52}$ Although cooperatives in the Var and Hérault departments (southern France) and the Priorat district (Catalonia) did not measure alcohol content (Mandeville, Étude, pp. 165-8; Badell, 'Valoración', p. 220), in the Var this was partially compensated by the fact that cooperatives paid different prices for each grape variety. In Hérault almost all the grape came from the plains and had a low alcohol content. And in the Priorat almost all the grape came from slopes and was high in sugar. For this reason, the general assembly of a Priorat cooperative prohibited members from grafting their vines with varieties that were not traditional in the area. At the same cooperative, when a member reported that some vineyards were being pruned using a technique that would increase the harvest at the expense of the sugar content, a committee inspected all the vines and imposed heavy fines on the opportunists (Audí, 100 anys, pp. 184-5).
} 
majority of members decided to allow behaviours that did not coincide with best possible practices. According to the manager of one cooperative, gaining quality by strictly monitoring variables that were not alcohol content made the product more expensive and difficult to sell. ${ }^{53}$ For years another cooperative employed an engineer with great powers to prescribe phytosanitary treatments for vines, organise the harvest and reject grape that was not in perfect condition. He was dismissed in 1915 because the members considered that the increases in the selling prices thus achieved were not sufficient to cover his salary. ${ }^{54}$ For similar reasons, although the articles of association of almost all cooperatives said that unripe grape would be rejected, the members of some cooperatives decided it should be accepted. ${ }^{55}$ But the detriments it caused to the cooperative were not paid for by all the members but only by those who contributed unripe grape, because unripe grape has less sugar than ripe grape and grape was paid for according to its sugar content.

In any event, laxity did not mean the absence of rules, because cooperatives set limits on what would be tolerated and if those limits were exceeded they would intervene. Merchants who bought grape to make table wine more than likely behaved in the same way. A French company purchased large amounts of grape from the Priorat district, made wine in rented wineries and sent it to France. When the first cooperatives appeared in the Priorat, the company stopped buying grape and started purchasing their wine ${ }^{56}$ For the purpose of the argument in this article, the quality of cooperative wine in absolute terms did not matter. But it did have to be at least of a similar quality to the wine the company had been producing, which would have been impossible to achieve if the cooperatives had been unable to control the quality of the grape at least as effectively as the company.

5. Why then were there so few cooperative wineries?

If, like Danish dairies, cooperatives have a very high market share, 'private' marketing networks become smaller and farmers who are not members find it difficult to sell their

\footnotetext{
${ }^{53}$ Flamarique, 'Cooperativas'.

${ }^{54}$ Saumell, Crisi, p. 380

${ }^{55}$ Campllonch, CellerS, p. 85

${ }^{56}$ Audí, 100 anys.
} 
production and tend to join a cooperative. Before the Second World War, cooperative wineries were a long way from reaching the critical point required for a virtuous circle of this type to make itself felt. As the major winegrowers kept largely outside the cooperative movement, ${ }^{57}$ the 'private' marketing networks continued to have a major presence and any small winegrower could continue to use them. The cooperatives themselves thought that selling directly to consumers forced them to assume too many risks and so (contrary to the myth) they did not try to make the intermediaries disappear and sold their wine to merchants.

According to their propagandists, cooperative wineries offered three main advantages. Firstly, their mechanical presses enabled members to obtain between 6 and 11 per cent more wine per kilogram of grape than small farmers who used manual presses. Unfortunately for the cooperatives, purchasing mechanical presses individually was perfectly within the capabilities of wealthy winegrowers. Furthermore, the greater gains in productivity in the range indicated above could only be obtained using continuous mechanical presses, which simultaneously generated three qualities of must, the worst of which only served to produce cloudy, unpleasant wine. ${ }^{58}$

If winegrowers stored wine in their private wineries hoping prices would rise, they risked having to sell it at any price immediately before the next harvest in order to make room for the new crop. In theory, the second advantage of cooperatives was that they could store wine for more than a year. That is effectively what happened from the 1950s on, but previously that advantage was another myth. The technical advances introduced by 'scientific viniculture' made stored wine much less likely to go bad at the beginning of the twentieth century than had been the case forty years before. And the wine produced by the cooperatives (which used to rely on technicians to direct the winemaking process, applied relatively stringent hygiene measures, etc.) was less likely to spoil than the wine previously produced individually by their members. But even so,

\footnotetext{
${ }^{57}$ See Riba, Cellers, p. 19, or the quote Simpson, 'Cooperation', p. 123, provides from Guide, Les associations, p. 138. European cooperative wineries were only able to attract as members a large number of well-off winegrowers during the period following the Second World War (Loubère, Wine); MedinaAlbadalejo, 'Cooperativismo', and Piqueras, Campo Arcís, provide good examples of this. ${ }^{58}$ Campllonch, Cellers, pp. 146-54. These were the presses used by the majority of Catalonian cooperative wineries, which according to an expert had chosen well 'because to produce wines that are competitive, without the buyer paying one peseta more for the best quality, the important thing is to obtain the highest possible yield' (Torrejón, Bodegas, p. 81).
} 
the probability that wine stored for more than a year would go bad continued to be high, 'which means that,' wrote a technician in 1923, 'nobody wants to keep wine, except when it comes to wines destined to be matured and bottled, beyond the new harvest. ${ }^{59}$ Moreover, having tanks that were enormously large in relation to the processed crop would have meant more construction costs, bigger loans and an increase in unit production costs. Consequently, few cooperatives had such tanks and most had to sell the wine before the next harvest. ${ }^{60}$

The third advantage stemmed from the supposed negotiating power that selling large quantities of wine gave to the cooperatives. In fact, during the many times of overproduction selling large amounts was more of an inconvenience than anything else. At such times, cooperatives temporarily withdrew fairly large volumes of wine from the local markets, to the benefit of growers who were not members. For that reason, during difficult years the members of many cooperatives requested permission to sell the wine that corresponded to them individually. To reduce risk, some Catalonian cooperatives sold their wine to a very small number of merchants and sometimes sold their entire production for several years to a single merchant. ${ }^{61}$ In exchange for the certainty they would sell the wine, they were prepared to drop the price. In southern France, where cooperatives claimed to provide winegrowers with a 'standard price' which was 'sufficiently remunerative', ${ }^{62}$ something similar must have happened.

It can therefore be assumed that if in the early twentieth century few cooperative wineries were created it was mainly because the prices members received for the wine were not clearly higher than the prices obtained by non-members. But they could not be much lower either, because new cooperative wineries were continually being created and very few cooperative wineries disappeared once the loan to build the facilities had been paid back in full. Finding data series to verify these hypotheses is difficult, but the data from the table-wine making cooperatives shown in Figure 2 seem to confirm them.

\footnotetext{
${ }^{59}$ Bernácer, Comercio, p. 7.

${ }^{60}$ In 1928, Italian cooperative wineries were able to store 1,200,000 $\mathrm{hl}$ and they produced 1,000,000 $\mathrm{hl}-$ 2 per cent of all Italian wine (Clique, Caves, p. 253). According to Marsais (Caves, p. 49), by 1930 a typical French cooperative had a capacity of 10,000 hl and on average produced 8,000 hl.

${ }^{61}$ Saumell, Crisi; Gavaldà and Santesmases, Història; Planas, Viticultura, pp. 246-7; Audí, 100 anys.

${ }^{62}$ Mandeville, Étude, p. 35.
} 
All the cooperatives in Figure 2 produced table wine except for the Alella cooperative, which sold its quality wine at relatively very high net prices. In spite of this, its members were dissatisfied for a long time. As it aged the wine for at least three years, the harvest was paid for with a three-year delay - and sometimes even later, because income from sales had to be used to cover operating costs. The situation only changed around 1930, when the prestige that the cooperative had been earning over a quarter of a century enabled the volume of wine sold and its prices to grow. ${ }^{63}$

All the cooperatives in Figure 2 are from Catalonia except the one in San Martín de Unx (Navarre). Prices of the Catalonian table-wine making cooperatives are presented in three series (the average price at which the six cooperatives sold their wine, the price at which the Ripollet cooperative sold it and the price at which the Llorenç cooperative sold it) because of suspicions that the Ripollet and Llorenç prices represent only part of the sales made. But when a Kruskall-Wallis test was used to check whether there was any statistical evidence that the series of wine prices in Catalonia, the average prices of the six cooperatives and the average prices of the eight cooperatives (that is to say, the six cooperatives plus Ripollet and Llorenç) were different, the results were negative $(\mathrm{p}=0.94)$. What happened in the Marsillargues cooperative, one of the most powerful in France, points in the same direction as such series: between 1911 and 1925 the Marsillargues cooperative sold its wine for an average of 57.3 francs (current prices) per hectolitre and the average regional price was 59.2 francs, ${ }^{64}$ but a Mann-Whitney test shows that cooperative prices and 'market prices' did not differ significantly $(p=0.73)$.

It is true that, even though the selling prices of wine were similar, thanks to the cooperative the small winegrower members could obtain a little more wine from their grapes than they would have achieved in their wineries using traditional presses. But in return, until the loan to build the facilities was paid off, the cooperative retained a portion of the wine they were entitled to every year. And to be members they had to accept joint and several liability for the loan and therefore they had to run the risk that, due to malfunctioning or any other circumstance, the cooperative would disappear before the loan was paid off - something that rarely happened, but did sometimes occur.

\footnotetext{
${ }^{63}$ Alella Vinícola, Cincuentenario.

${ }^{64}$ Congrès, XIV Congrès, p. 168; Pech, Entreprise, pp. 512-3.
} 
Although joining a cooperative winery was not the same as joining a free-rider club, most winegrowers must have simply thought that the disadvantages of joining them outweighed any benefits that could be gained. In consequence, the first cooperative wineries managed to attract few winegrowers.

\section{Conclusions}

Since cooperatives began to receive large subsidies in the 1950s to produce whatever type of wine they wanted, they had the perverse stimuli required to be totally unconcerned about the quality of their wine and they could even afford to be 'inefficient firms'. ${ }^{65}$ The literature on wine has projected that image to the past and assumed that it was happening from the moment the very first cooperative wineries were created. This article has defended a very different view.

This article has argued that the first cooperative wineries were perfectly able to control the quality of the grape they received. The fact that, with few exceptions, they produced table wine was simply because that was the type of product most consumers wanted. But there were many different prices of table wine and the cooperatives generally managed to impose on their members the necessary discipline to achieve the type of table wine they were interested in producing. They did not, however, manage to offer the winegrower, and large-scale winegrowers in particular, sufficiently attractive services to compensate for the disadvantages of being a member. In turn, the absence of well-off winegrowers among the members hindered access to credit and economies of scale for the cooperatives, made it easier for the 'private' wine trade to continue to have a hegemonic presence and made cooperatives less attractive for all winegrowers.

According to a manual for cooperative members in the early 1920s, 'The demands and convenience of the consumer market must be met first of all. If current circumstances change $[\ldots]$ we would need to think about replacing procedures that sacrifice quality in order to obtain quantity' ${ }^{66}$ In the late twentieth century

\footnotetext{
65 According to Medina-Albadalejo, 'Co-operative wineries', around 1970 the ease with which Spanish cooperative wineries could access state-subsidised loans allowed them to be able to offer their members very attractive services and, at the same time, they were 'inefficient firms', due to their excessive indebtedness - something that obviously mattered very little to their members.

66 Torrejón, Bodegas, p. 82.
} 
circumstances did indeed change. First, table wine was losing its appeal for consumers and demand dropped. Then European authorities began modifying their subsidy policies and cooperatives were forced to change. Although change is not always easy, because the members of many cooperatives are mainly elderly farmers or part-time farmers who would prefer everything to stay the same, it has often been accomplished successfully. ${ }^{67}$ In fact, the number of cooperatives producing quality wines, and even top quality wines, is increasing. But their labels do not usually indicate that the wines come from cooperatives, because reputation in the present depends on what has been done in the past.

References

Alella Vinícola (1956). Cincuentenario de la fundación de la bodega cooperativa Alella Vinícola. Alella.

Audí, P. et al. (2013). 100 anys fent vi. Centenari de la Cooperativa Falset-Marçà. Falset.

Badell, L. (1940). 'Valoración de las uvas en las bodegas cooperativas'. Anales de la Escuela de Peritos Agrícolas y Superior de Agricultura y de los Servicios Técnicos de Agricultura 1(3): 217-241.

Bernácer, G. (1923). Comercio de vinos. Madrid: Calpe.

Biarnès Anne \& Touzard, J-M. (2003). 'La rémunération différenciée du raisin dans les coopératives du Languedoc'. Les cahiers de l'économie sociale 2: 215-231.

Blic, R. (2013). La crise viticole et les coopératives de production en Côte-d'Or. Paris. Campllonch, I. (1917). Cellers cooperatius de producció i venda. Barcelona: Giró.

Cañizo, J. (1937). Bodegas cooperativas. Madrid: Espasa-Calpe.

Cárdaba, M. \& Musquera, S. (2007). El celler cooperatiu d'Espolla. Figueres: Brau. Chalmain, Ph. (1981). 'Coopérateurs et coopératives: l'exemple de la coopérative viticole'. Revue des études coopératives 252(2): 75-102.

Clique, H. (1931). Les caves coopératives de vinification en Bourgogne. Paris: Sirey. Cogeca [General Committee for Agricultural Cooperation in the European Union] (2010). Agricultural cooperatives in Europe. Main issues and trends. Brusels.

\footnotetext{
${ }^{67}$ On southern France, see Biarnès and Touzard, 'Rémunération'.
} 
Colomé, J. et al. (2013). 'Les cycles de l'économie viticole en Catalogne. L'évolution du prix du vin entre 1680 et 1935'. Annales du Midi 125(281): 29-55.

Congrès (1927). XIV Congrès national de la mutualité, de la coopération et du crédit agrícoles. Perpignan: L'indépendent.

Delmastro, M. (2005). 'An investigation into the quality of wine: Evidence from Piedmont'. Journal of Wine Research 16(1): 1-17.

Fernández, E. (2012). ‘Especialización en baja calidad: España y el mercado internacional del vino, 1950-1990'. Historia Agraria 56: 41-76.

Fernández, E. \& Pinilla, V. (2018). 'Spain'. In K. Anderson \& V. Pinilla (Eds.) Wine globalization: A new comparative history. New York: Cambridge University Press.

Fernández, E. \& Simpson, J. (2017). 'Product quality or market regulation? Explaining the slow growth of Europe's wine cooperatives, 1880-1980'. Economic History Review 70(1): 122-42.

Ferrer Alós, L. (2008). 'El sindicat agrícola de Llobregat de Bages'. Dovella 97: 40-45.

Flamarique, V. (1914). 'Cooperativas para la venta de vinos. Su organización y funcionamiento. Historial de las existentes en España'. In Congreso Nacional de Viticultura. Pamplona: Imprenta Provincial. p. 109-124.

Fuguet, J. (1987). 'El celler del sindicat agrícola de Rocafort de Queralt'. Aplec de Treballs 8: 39-58.

Fuguet, J. \& Mayayo, A. (1994). El primer celler cooperatiu de Catalunya. Barcelona: Generalitat de Catalunya.

García, J. P. (2016) Bullas. 100 años de cooperativismo vinícola. Bullas.

Garrido, S. (1996). Treballar en comú. El cooperativisme agrari a Espanya. Valencia: Alfons el Magnànim,.

Garrido, S. (2014a). 'Water management, Spanish irrigation communities and colonial engineers'. Journal of Agrarian Change 14(3): 400-418.

Garrido, S. (2014b). 'Plenty of trust, not much cooperation. Social capital and collective action in early twentieth century Spain'. European Review of Economic History 18(4): 423-432.

Garrido, S (2017). 'Sharecropping was sometimes efficient: sharecropping with compensation for improvements in European viticulture'. Economic History Review 70(3): 977-1003.

Garrido, S (2020). 'Inequality and conflict as drivers of cooperation: the location of 
cooperative wineries in pre-1936 Spain'. Cliometrica https://doi.org/10.1007/s11698-020-00210-5 .

Gavaldà, A. (1988). L'associacionisme agrari a Catalunya. El model de la Societat Agrícola de Valls. Valls: Biblioteca Estudis Vallencs.

Gavaldà, A. \& Santesmases, J. (1993). Història econòmico-social de les cooperatives agrícoles de Nulles. Valls: Institut d'Estudis Vallencs.

Gavignaud-Fontaine, G. (1986). 'Les caves coopératives, bastions de la viticulture populaire en Roussillon au XXe siècle'. La Revue de l'Économie Sociale 7:1122.

Gervais, M. (1913). La coopération en viticulture. Paris: Laveur.

González Inchaurraga, I. (2006). El marqués que reflotó el Rioja. Madrid: Editorial Empresarial.

Guide, Ch. (1926). Les associations coopératives agrícoles. Paris: Association pour l'Enseignement de la Coopération.

Hansmann, H. (1999). 'Cooperative firms in theory and practice'. Finnish Journal of Business Economics 48(4): 387-403.

Heenriksen, I., Hviid, M., and Sharp, P. (2012). 'Law and peace: contracts and the success of the Danish dairy cooperatives'. Journal of Economic History 72(1): 197-224.

Henriksen, I., Lampe, M., and Sharp, P. (2011). 'The role of technology and institutions for growth: Danish creameries in the late nineteenth century'. European Review of Economic History 15(3): 475-493.

Henriksen, I., Mclaughlin, E. and Sharp, P. (2015). 'Contracts and cooperation: the relative failure of the Irish dairy industry in the late nineteenth century reconsidered'. European Review of Economic History 19(4): 412-431.

Ibarra, R. (1998). 'El sindicat agrícola d'Alió i el seu celler cooperatiu'. Quaderns de Vilaniu 34: 43-85.

Llorca, J. (2008). 'La cooperativa agrícola. Punt i final de l'agricultura terrassenca?' Terme 23: 149-69.

Loubère, L. (1978). The red and the white. The history of wine in France and Italy in the nineteenth century. New York: State University of New York Press.

Loubère, L. (1990). The wine revolution in France. The twentieth century. Princeton: Princeton University Press.

Mandeville, L. (1914). Étude sur les sociétés cooperatives de vinification du Midi de la 
France. Toulouse: Douladoure-Privat.

Marsais, P. (1931). Les caves coopératives en France. Paris: Compagnie d'Orléans.

Martos, (1986). 'El sindicato agrícola de Ripollet'. In Jornades sobre la viticultura de la conca mediterrània. Tarragona: Diputació. p. 462-480.

Mayayo, Andreu (Ed.) (2008). L'empemta d'un poble. Centenari de la Cooperativa Vinícola de Sarral. Sarral.

Medina-Albadalejo, F. (2015) 'Co-operative wineries: Temporal solution or efficient firms? The Spanish case during late Francoism'. Business History 57(4): 589613.

Medina-Albadalejo, F. (2018). 'Cooperativismo y desarrollo rural en el viñedo español durante el siglo XX'. In D. Soto \& J. M. Lana (Eds.) Del pasado al futuro como problema. La historia agraria contemporánea española en el siglo XXI.

Zaragoza: Prensas Universitarias de Zaragoza. p. 163-188.

Muntadas, R. (2001). Alella Vinícola en imatges, 1906-2001. Alella.

Muruzabal, J. (2014). Centenario de la bodega cooperativa de San Martín de Unx. San Martín de Unx.

Ostrom, E. (1990). Governing the commons. The evolutions of institutions for collective action. Cambridge: Cambridge University Press.

Pan-Montojo, J. (1994). La bodega del mundo. La vid y el vino en España (1800-1936). Madrid: Alianza.

Pech, R. (1975). Entreprise viticole et capitalisme en Languedoc-Roussillon. Toulouse: Université Toulouse - Le Mirail.

Pena, M. (2008). Breu història del celler de Capçanes. Capçanes: Celler de Capçanes.

Pennerstorfer, D. \& Weiss, C. (2013). 'Product quality in the agri-food chain: do cooperatives offer high-quality wine?' European Review of Agricultural Economics 40(1): 143-162.

Pinilla, V. \& Ayuda, M.-I. (2008). 'Market dynamism and international trade: a case study of Mediterranean agricultural products, 1850-1935'. Applied Economics 40(5): 583-595.

Piqueras, J. (1981). La vid y el vino en el País Valenciano. Valencia: Alfons el Magnànim.

Piqueras, J. (2009). Campo Arcís. Cooperativismo y viticultura. Campo Arcís: Cooperativa San Isidro.

Planas, J. (2013). Viticultura i cooperativisme. La comarca d'Igualada, 1890-1939. 
Barcelona: Abadia de Montserrat.

Planas, J. (2014). 'Características y factores explicativos del primer cooperativismo agrario'. CIRIEC-España, Revista de Economía Pública, Social y Cooperativa 80: 111-s35.

Planas, J. (2016). 'The emergence of winemaking cooperatives in Catalonia'. Business History 58 (2): 263-281.

Planas, J. (2017). 'State intervention in wine markets in the early 20th century'. Revista de Historia Económica - Journal of Iberian and Latin American Economic History 35(2): 175-206.

Planas, J. \& Medina-Albadalejo, F. (2017). 'Too little intervention or too much? The contribution of the State to the development of wine cooperatives in Spain'. Revista de Historia Industrial 70: 77-107.

Planas, J.\& Medina-Albadalejo, F. (2018). 'Las Bodegas cooperativas y la comercialización del vino en España'. Investigaciones de Historia Económica, article in press, doi: 10.1016/j.ihe.2018.04.001.

Planas, J. \& Vallès, J. M.. (2015). 'L’Espluga de Francolí, model del cooperativisme vitivinícola català'. In J. Colomé et al. (Eds.) Vinyes, vins i cooperativisme vitivinícola a Catalunya. Barcelona: Abadia de Montserrat. p. 437-471.

Postel-Vinay, G. \& Robin, J-M. (1992). 'Eating, working, and saving in an unstable world: consumers in nineteenth-century France'. Economic History Review, 45(3): 494-513.

Pujol, J. (1984). 'Les crisis de malvenda del sector vitivinícola català entre el 1892 i el 1935'. Recerques 15: 57-78.

Puig, E. (1984). Celler cooperatiu Ricardell. Girona: Alzamora.

Raventós, M. (1911). La verema. Barcelona: Verdaguer.

Rinaudo, Y. (1994). 'Coopérative et progrès : les caves viticoles du Midi de la France'. Cahiers de la Meditérranée 48: 167-183.

Riba, J. (1917). Cellers cooperatius de producció i venda. Barcelona: Riera.

Robinson, J. (Ed.) (2005). The Oxford companion to wine. Oxford: Oxford University Press.

Roma, P., Di Martino, G. and Perrone, G. (2013). 'What to show on the wine labels: a hedonic analysis of price drivers of Sicilian wines'. Applied Economics 45 (19): $2765-2778$

Rouanet, André (1935). Le problème International du vin. Montpellier: Mari-Lavit. 
Roudié, Ph. (1988) Vignes et vignerons du Bordelais: 1850-1980. Paris: CNRS.

Santesmases, J. (1996) El cooperativisme agrari a Vila-rodona. Vila-rodona: Centre d'Estudis del Gaià.

Saumell, A. (1998) Crisi vinícola, renovació tecnològica i cooperativisme. Doctoral thesis. Universitat Pompeu Fabra. Barcelona.

Saumell, A. (2002). Viticultura i associacionisme a Catalunya. Tarragona: Diputació.

Saumell, A. (2003). La Cooperativa Agrícola i Caixa Agrària de Llorenç del Penedès (1889-1936). Llorenç del Penedès.

Soto, M. (1995). La bodega cooperativa La Baronia de Turís. Turís.

Schamel, G. (2015). 'Can German wine cooperatives compete on quality?' BIO Web of Conferences 5: 03003.

Simpson, James. (2000). 'Cooperation and cooperatives in southern European wine production'. New Frontiers in Agricultural History 1: 95-126.

Simpson, James (2011). Creating wine: the emergence of a world industry, 1840-1914. Princeton: Princeton University Press.

Tardy, L. (1929). 'La coopération vinicole en France'. Le Musée Social 36, 11: 417-46.

Teixidó, J. (1997). 'La Societat Agrícola de Cabra del Camp (1895-1936)’. Quaderns de Vilaniu 32: 51-75.

Torrejón, Á. (1923). Bodegas Industriales. Madrid: Helénica.

Vallès, J. (2014). El celler de Baix. Valls: Cosetània. 


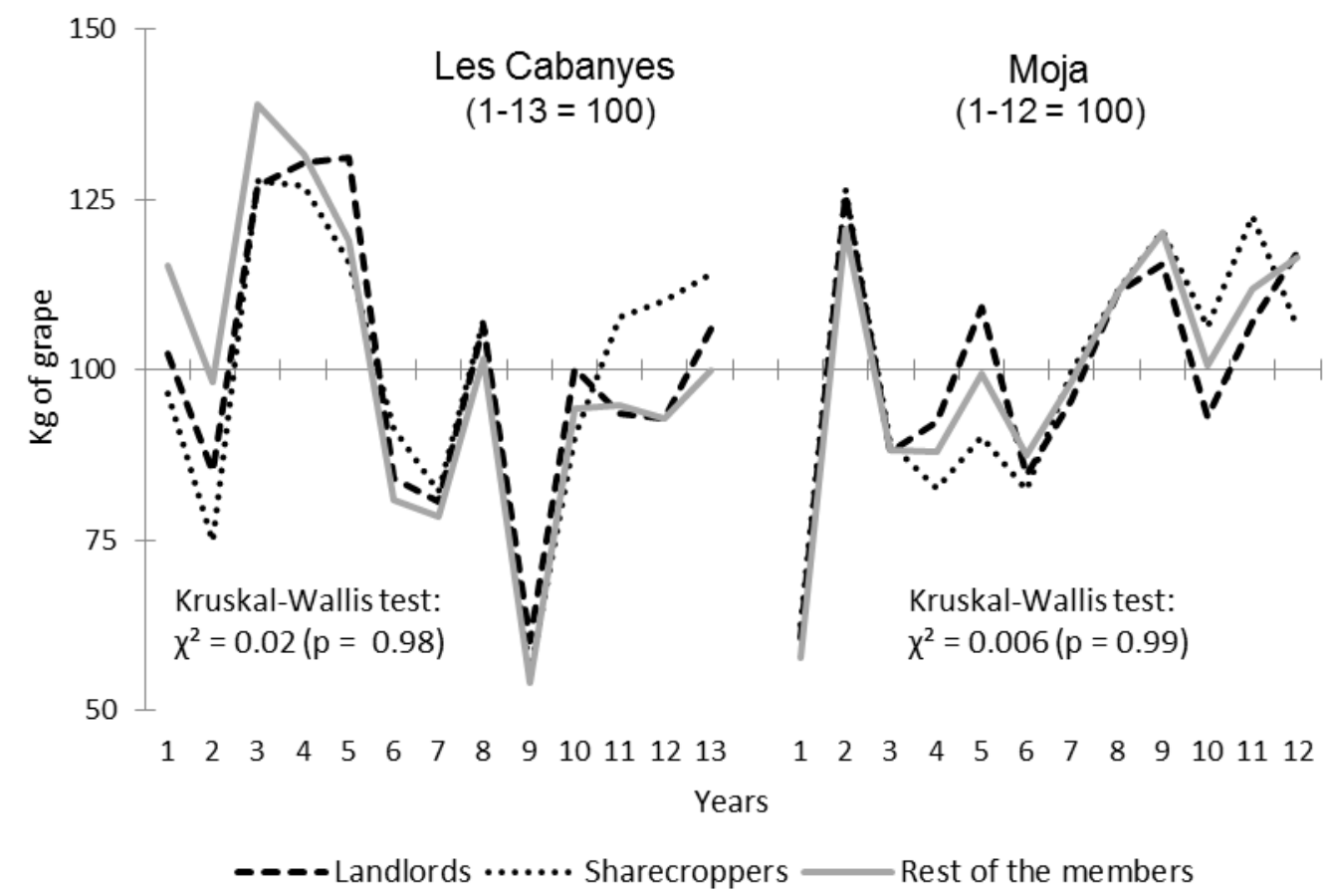

Figure 1 Grape contributed by members of two cooperative wineries (index numbers). Sources: Author's elaboration with Saumell's, Crisi, data. On Les Cabanyes there is information for 13 years in the period 1920-1935; on Moja, for 1924-1935. In Les Cabanyes members had to deliver all the grape from their vineyards located at less than two kilometres from the cooperative and in Moja at less than $0.5 \mathrm{~km}$. 


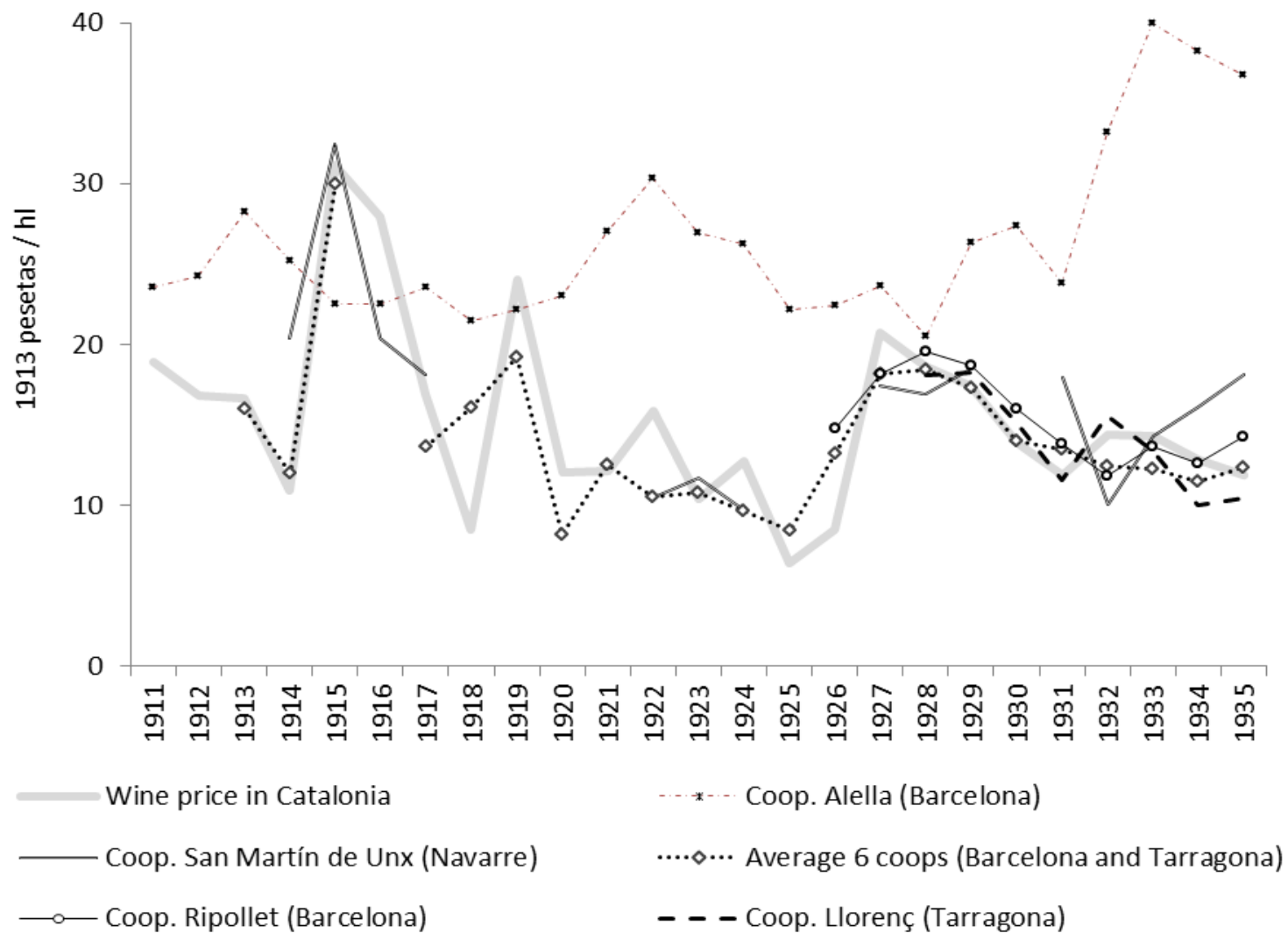

Figure 2. Price of the wine sold by various Spanish cooperative wineries. Sources: Catalonia: Colomé et al., 'Les cycles'; Alella: Alella Vinícola, Cincuentenario; San Martín de Unx: Muruzabal, Centenario; average 6 cooperatives: Cabanyes, Banyeres, Moja and Vendrell (Saumell, Crisi), Espluga de Francolí (Vallès, Celler), and Vilarodona (Santesmases, Cooperativisme); Ripollet: Martos, 'Sindicato'. Llorenç: Saumell, Cooperativa. Author's elaboration. 